\title{
Women Entrepreneurship in India
}

\author{
N.Md.Faiyaz Ahmed \\ M.com, M.Phil, PGDADV, NET \\ Assistant Professor of Commerce (Finance \& Accounts), \\ Islamiah College (Autonomous), \\ Vaniyambadi- 635 752, Velore District, Tamilnadu
}

\section{INTRODUCTION}

Women Entrepreneurs may be defined as the women or a group of women who initiate, organize and operate a business enterprise. Government of India has defined women entrepreneurs as an enterprise owned and controlled by a women having a minimum financial interest of $51 \%$ of the capital and giving at least $51 \%$ of employment generated in the enterprise to women.

Women in business are the surprising phenomena India. Women entrepreneurs are emerged in business due to push and pull factors such as Saddled with household chores, death of bread winner and domestic responsibilities of women, want to get independence Such situation is described as pull factors. While in push factors women engaged in business desire to show their talent, to gain recognition, importance, social status etc.

Indian women are not only educated, talented, confident, ambitious, career oriented but they also know their minds! This Hence, foresight, timemanagement ability, patience, negotiating and budgeting skills of an entrepreneur are ingrained in the modern woman

\section{Problems of Women Entrepreneurs in India:}

1. Male dominant social order is the stumbling block in their way towards business success. Male members think it a big risking fator a ventures run by women.

2. The bankers put unrealistic and unreasonable securities to get loan to women entrepreneurs.
3. Women's family obligations also bar them from becoming successful entrepreneurs

4. Indian women give more emphasis to family ties and relationships. Married women have to make a fine balance between business and home.

5. Lack of knowledge of availability of the raw materials and low-level negotiation and bargaining skills

6. Another argument is that women entrepreneurs have low-level management skills. They have to depend on office staffs and intermediaries, to get things done, especially, the marketing and sales side of business.

7. Low-level risk taking attitude

8. They lack encouragement and motivation from others. Men in fact discourage them and are jealous of their success in business.

\section{How to Develop Women Entrepreneurs}

Consider women as specific target group for all developmental programmes.

Better educational facilities and schemes should be extended to women folk from government part.

$>$ Training in entrepreneurial attitudes should start at the high school level through well-designed courses which build confidence through behavioral games. A Women Entrepreneur's Guidance Cell set up to handle the various problems of women entrepreneurs all over the state 
International Journal of Trend in Scientific Research and Development (IJTSRD) ISSN: 2456-6470

Women training programme should be organised that taught to recognize her own psychological needs and express them.

$>$ The financial institutions should provide more working capital assistance both for small scale and for large scale ventures

$>$ Training and counseling on a large scale of existing women entrepreneurs to remove psychological causes like lack of self-confidence and fear of failure.

$>$ Skill development programme to be start in women's polytechnics and industrial training institutes and women's Colleges.

$>$ Programmes for encouraging entrepreneurship among women are to be extended.

$>$ Announcing more governmental schemes to motivate women entrepreneurs to engage in small scale and large scale business ventures.

$>$ Vocational training to be extended to women community that enables them to understand the production process and production management

$>$ Encourage women to start their own business. Give them ides suggestion about the various business projects. Activities in which women are trained should focus on their marketability and profitability.

\section{Business opportunity for Women entrepreneur:}

$>$ Eco-friendly technology

$>$ IT enabled enterprises

$>$ Tourism industry

$>$ Telecommunication

$>$ Home Made products

( Pickles, Papad, embroidery product etc)

$>$ Event Management

$>$ Plastic materials

$>$ Sericulture

$>$ Floriculture

$>$ Herbal \& health care

$>$ Food, fruits \& vegetable processing

$>$ Apparel Manufacturing

$>$ Retail shops

$>$ Tailoring, Fashion designing

$>$ Packaging

$>$ Designing

$>$ Institution ( Tutorial, Computer Educational Institution )

SUCCESSFUL WOMEN ENTREPRENEURS IN INDIA:

\section{Ekta Kapoor, Creative Director, Balaji Telefilms}

Kapoor, born on June 7, is the Creative Head of Balaji Telefilms. She is aptly called the reigning queen of Indian television industry. The serials produced by her company Balaji Telefilms are a smashing hit with the masses and dominate all the major T.V. channels in India. Ekta's serials have not only captured the imagination of the masses but also their soul. She did her schooling from Bombay Scottish School and after that she joined Mithibai College. After the college her great father jitendra suggest her to open her great balaji TV production house which now a days no.1 telefilms. At that time ekta only turned 19 . She enters like child in Indian television and become the queen of Indian TV serials. Her company has produced more than 25 serials and each one is being shown, on an average, four times a week on different television channels

\section{Jyoit Naik, President, Lijjat Papad}

SMGULP was a cooperative system in which women over the age of 18 could become members. Starting humbly, with an initial capital of Rs 80 , borrowed from a local money lender and social worker, SMGULP grew phenomenally. In 2002, it had a turnover of Rs 3 billion and exports worth Rs.100 million. It employed 42,000 people in 62 divisions all over the country. SMGULP was the brain child of seven semi-literate Gujarati housewives, who started a venture to create a sustainable livelihood using the only skill they had-cooking. Jyoit Naik is the woman behind the success of this venture.

\section{Kiran Mazumdar-Shaw, Chairman and Managing Director, Biocon}

She has been described as "India's Biotech Queen" by The Economist while the New York Times calls her "India's mother of invention". Kiran Mazumdar Shaw started her professional career as trainee brewer in Carlton \& United Beverages in 1974. In 1978, she joined as Trainee Manager with Biocon Biochemical Limited in Ireland. In the same year, Kiran Mazumdar Shaw founded Biocon India in collaboration with Classes, Biocon Biochemical Limited, with a capital of Rs.10, 000. She initially faced many problems regarding funds for her business. Banks were hesitant to give loan to her as biotechnology was a totally new field at that point of time and she was a woman entrepreneur, which was a rare phenomenon 


\section{Naina Lal Kidwai, Deputy, Chairman Max Financial Services Ltd.}

Naina Lal Kidwai (born 1957) is the Chief Executive Officer of The Hongkong and_Shanghai Banking Corporation India branches. She is the first Indian woman to graduate from the Harvard Business School. Naina Lal Kidwai is the former Group General Manager and Country Head of HSBC India. She has been awarded with Padma Shri, one of the highest civilian honours (2007). She is currently the Chairman of Max financial Services Ltd.

\section{Preetha Reddy, Vice Chairperson, Apollo Hospitals Group.}

She is the daughter of Apollo founder, Dr. P.C. Reddy .She was born in 1957 in Hyderabad,. Under Preetha Reddy's leadership, The Apollo Specialty Hospital has emerged as a major oncology referral centre in Asia, and this hospital is one of the few places with facility to offer bone marrow transplantation. The hospital was first to perform cord blood transplantation in India.

Currently, the Apollo Group has more than 6,400 beds and 16,500 employees, and has emerged as an integrated global healthcare provider, attracting patients from all over India, the other countries of the Indian subcontinent like Bangladesh, Bhutan, Nepal, and Pakistan, the Middle East and the Gulf states

\section{Preeti Vyas Giannetti, CEO/ Vyas Gianneti Creative}

She's unique. The only Creative Director who is CEO and ranked as one of the 25 most powerful women in Indian business. She is famous as a designer, but prefers to be seen as a creative strategist. Started by Preeti Vyas Giannetti in 1997, VGC was the very first agency in the country to provide holistic communication solutions to its clients, ranging from advertising to design and interactive media. Today, it is a total brand communications agency with a dedicated team of over 75 professionals in Delhi and Mumbai, blue-chip clients and capitalized billings of over $\$ 40$ million. This includes providing holistic communication strategies and services such as Advertising, Brand and Corporate Identity, Packaging Design, Publication Design, Retail Displays, Graphic Design, Web Design, etc. VGC recently launched its sports firm- Vyas Giannetti Creative Sports- India.

\section{Radhika Roy, Managing Director/ NDTV}

The story goes that Radhika Roy, NDTV's founder (she set up the company in 1987) and chief executive producer. For the two new channels, one in English and the other in Hindi, Roy is said to have painstakingly worked out all the details -- content, fixed point chart (the programme schedule), set design, and the look and feel of the products on air and managing the company's day-to-day affairs. She is the guiding vision and force behind NDTV.

\section{Rama Bijapurkar, Independent Management Consultant}

Rama Bijapurkar is one of India's most respected thought leaders on market strategy and consumer related issues in India. She is also a keen commentator on social and cultural changes in the evolving liberalizing India. She has her own market strategy consulting practice and works with an impressive list of Indian and global companies, guiding the development of their business-market strategies. She describes her mission as bringing "market focus to business strategy".

\section{Ritu Kumar, Fashion Designer}

Ritu Kumar is synonym of the Indian fashion industry; she created inroads to the world of fashion with her own recipe of blending tradition and modernity to produce the finest example of the work of art. Ritu has been regularly designing the wardrobes for the Indian beauty pageants comprising swimwear, evening wear, traditional Indian wear, casual wear and formal evening gowns. Some of her global achievements include the wardrobes for the Miss India, for participation in the International beauty pageants like Miss Universe, Miss World \& Miss Asia Pacific respectively. Many times she has won the award for the Most Outstanding Evening Gown in International pageants.

\section{Shahnaz Husain CEO, Shahnaz Herbals}

Shahnaz Husain Group, largest producers, ayurvedic, herbal products, world, personal profile, producing, marketing, ayurvedic products, substitute, chemical cosmetics, niche product, Indian market, brand retailed, major stores, Shahnaz Husain products, business style, subsidiary, ancillary activities, training institutes, Ayurvedic massage centers, health resorts . Her company, Shahnaz Husain Herbals is one of the 
International Journal of Trend in Scientific Research and Development (IJTSRD) ISSN: 2456-6470

largest manufacturers of herbal products in the world. It formulates and markets over 400 products for various beauties and health needs.

A number of awards, both national and international have been conferred on Shahnaz Husain. Some of them are "The Arch of Europe Gold Star for Quality", "One of the Leading Women Entrepreneurs of the World", "The 2000 Millennium Medal of Honor", "Rajiv Gandhi Sadbhavana Award", etc.

\section{Shobhana Director/Hindustan Times Media}

Shobhana Bhartia (born 1957) is the ViceChairperson and Editorial Director of the india's leading newspaper and media house. She is considered to be one of the motive forces behind the transformation of the Hindustan Times "into a bright, young paper.

\section{Swati Piramal, Director, Piramal Healthcare Ltd}

Dr. Swati Piramal is executive director of Nicholas Piramal India and is one of the key persons responsible for the growth of Nicholas Piramal, a leading pharmaceutical player in India. Thanks to Dr. Swati Piramal, the annual revenue of the company increased from less than $\$ 4$ million in the late 1980's to over $\$ 450$ million.

\section{Zarina Mehta, CEO, Bindaas, Co-founder, UTV}

Zarina Mehta is one of the three founder directors of UTV Software Communications Limited and is on the board of the UTV group. One of India's leading integrated global media and entertainment group with business interests in Movies, Broadcasting, Interactive (Gaming), and Television \& New Media

Presently Zarina is the CEO of Bindass, India's first Local Youth Entertainment Brand. The Bindass' brand values of being fun, frank, fearless and Indian has created a community building platform to bring Indian Youth together using the power of TV (Bindass \& Bindass Movies launched in Sept 2007), web, mobile, Motion Pictures, Events \& Campus activities. Currently she is the Managing trustee of Swades Foundation.

\section{SOME SCHEMES:}

Prime Minister's Rozgar Yojana (PMRY) Swarnjayanti Gram Swarozgar Yojana (SGSY) Swarnjayanti Shahari Rozgar Yojana(SJSRY) Differential Rate of Interest Scheme(DRI) Micro Credit to Self-Help Groups(SHGs)

Stree Shakti Package - For women to put up smallscale industry

Mahila Udyam Nidhi Scheme -Supported by various state governments and banks

Annapurna scheme - For financing women to establish food catering units

Priyadarshini scheme -Offers loans to women entrepreneurs

Loan by Commercial Banks \& Financial Institutions

\section{CONCLUSION:}

Empowering women entrepreneurs is essential for achieving the goals of sustainable development and the bottlenecks hindering their growth must be eradicated to entitle full participation in the business. Apart from training programs, Newsletters, mentoring, trade fairs and exhibitions also can be a source for entrepreneurial development. As a result, the desired outcomes of the business are quickly achieved and more of remunerative business opportunities are found. Henceforth, promoting entrepreneurship among women is certainly a short-cut to rapid economic growth and development. Let us try to eliminate all forms of gender discrimination and thus allow 'women' to be an entrepreneur at par with men. 